Cahiers $d u$ MONDE RUSSE

\section{Cahiers du monde russe}

Russie - Empire russe - Union soviétique et États indépendants

$51 / 4 \mid 2010$

Sciences humaines et sociales en Russie à l'Âge d'argent

\title{
Hubertus F. Jahn, Armes Russland
}

\section{Elena Zubkova}

\section{(2) OpenEdition}

1 Journals

\section{Electronic version}

URL: https://journals.openedition.org/monderusse/7458

DOI: 10.4000/monderusse. 7458

ISSN: $1777-5388$

\section{Publisher}

Éditions de l'EHESS

\section{Printed version}

Date of publication: 25 November 2010

Number of pages: 834-837

ISBN: 978-2-7132-2316-7

ISSN: $1252-6576$

\section{Electronic reference}

Elena Zubkova, "Hubertus F. Jahn, Armes Russland", Cahiers du monde russe [Online], 51/4 | 2010, Online since 09 December 2011, connection on 02 September 2022. URL: http://

journals.openedition.org/monderusse/7458 ; DOI: https://doi.org/10.4000/monderusse.7458

This text was automatically generated on 2 September 2022.

All rights reserved 


\title{
Hubertus F. Jahn, Armes Russland
}

\author{
Elena Zubkova
}

\section{REFERENCES}

Hubertus F. JAHN, Armes Russland: Bettler und Notleidende in der russischen Geschichte vom Mittelalter bis in die Gegenwart. Paderborn: Ferdinand Schöningh, 2010.

1 The study of beggary has a long tradition. In recent European historiography, there is a field which studies practices of inclusion/exclusion of the «alien and poor» in a large historical (from Antiquity to the present) and comparative (covering several countries) scope $^{1}$. Until recently, Russia was not included in this research, surprisingly so because poverty and beggary in Russia have a long history and are important issues today. The appearance of "new beggars" sets the stage for studying the problem of "old beggars" and makes us look at the methods of dealing with it in pre-Revolutionary Russia and the Soviet Union. However, the historical excursions in the majority of recent publications are usually too brief and are at best based on research of the late nineteenth and early twentieth centuries. Soviet research on the lives of social outsiders, including beggars, came to an end in the late 1920s and resumed only in the early 1990s. At that time, topics somehow connected with the problem of poverty aroused historians' interest. But this interest was usually "secondary," i.e., beggary was considered "collateral" to other problems, as part of the context (for example, in publications on urbanization processes, social politics, charity, homeless children, the disabled, etc.).

2 Hubertus Jahn's book is the first complex historical research focusing on the problem of poor people and beggars in Russia. After the publication of this book, we can say that the tradition of studying Russian beggary, which stopped 80 years ago, is now restored. In addition, Jahn's work is very original and pioneering as far as approach, sources, and methodology are concerned.

3 Begging as a social phenomenon (or as a way of life) and beggars as a social group are rather difficult objects to study. The very use of the notion of "social group" when 
speaking of beggars is relative, and all the attempts to classify this group somehow are rather questionable. It is far more difficult to study the world of beggars "from inside" because beggars do not have their "own voice" and have not left any written records of their lives (p.13). Certainly it is impossible to create a general history of begging in Russia (p. 152), as well as a universal history of any other phenomenon. Moreover this kind of history is hardly necessary: the problem of begging is interesting not only in itself, but rather as part of other social problems and as a key for a better understanding of them. Among these are poverty, marginalization and deprivation, possibilities of resocialization for outsiders, social mobility, the quality of social policies, the relationship between "normal" society and social periphery.

4 The structure of Jahn's book rests on a threefold - chronological, geographical, and substantial - approach. From the chronological point of view, the study covers the eighteenth and nineteenth centuries, with historical incursions into earlier times and a brief history of begging in the twentieth and twenty-first centuries allowing us to see tendencies in the evolution of this social phenomenon. The geographical focus of the research is St. Petersburg. The content of the book the author himself defines as social imaginary poverty: he analyzes the problem of beggary in Russia in the light of the apprehension about poor people and the influence that the perception of these people exerted on the politics towards them. Thus, the focus of this research is not the social history of poverty or the description of beggars' daily lives, but the image of beggary and the "collective reaction to poverty" (Geremek).

5 At the same time, we must add that the book does not only describe images but also the reality of poverty, as well as the politics towards beggary: the peculiarities of the beggars' way of life in different Russian regions, the development of the legislation towards them, social control practices. There is also a chapter devoted to the activity of the St. Petersburg committee of classification and care for beggars (1837-1903), in which for the first time on the basis of a wide range of sources the history of this in many senses unique institution is reconstructed. The author also writes about the realities of beggars' daily lives in St. Petersburg and other places in Russia. His considerations are based on zemstvo statistics, ethnographical descriptions, state commissions materials, police files, and other sources. The appendix contains statistical tables of great interest which complement the author's rather concise descriptions.

6 The main sources for the analysis of the social imagination about the beggary are Russian fiction and popular magazines and newspapers of the eighteenth and nineteenth centuries, including tabloids (a total of approximately 60 periodicals). Jahn shows how the representation of beggars changed during the eighteenth and nineteenth centuries among the intellectual elite, and how the notion of beggar changed accordingly: from the image of "noble poverty" and from considering beggary as an object of moralization to the perception of beggary as a real social problem and poverty as a common and civil responsibility. The author observes that even Russian literary realism did not adequately reflect the world of real beggars because writers mainly focused on the creation of literary types of degraded people (p.121). The question as to what extent the descriptions in literature were the result of imagination is rather arguable, since many writers created their types in an "inclusive survey," which is mainly a sociological, rather than literary, method. But another thing is unquestionable: the types of beggars and images of poverty in literature shaped public opinion about beggary, and in addition, became an object of academic research thanks to the influence of literature. 

mass media) and the normative discourse of poverty and beggary in Russia. According to Jahn, these two discourses in general did not coincide with each other, they developed in different environments. Writers and journalists who wrote on questions of poverty often did not even know the history of Russian legislation about beggars and they sometimes proposed measures which were already implemented by the government (p. 68). But at the same time both discourses had at least one common feature: the influence of Western ideas and the European experience of solving the problem of beggary.

The influence of the European tradition on the Russian legislation on beggary, and on the real measures against it, became evident during the reign of Tsar Alexei Mikhailovich, but Peter the Great openly stated that he would directly adopt European experience and he did not always take Russian reality into account. Peter's attempts to eliminate the phenomenon of beggary failed, and Jahn argues that the reason for that was the fact that it was "reform from above." For example, Peter just imitated the practice which existed in some European cities ordering to replace the Russian custom of giving alms with centralized collection of donations for beggars' needs. It was not understood or welcomed by Russian people exactly because it was implemented as a forced innovation while in Europe it was introduced by the municipalities, i.e., "from below."

The ideas of European Enlightenment and rationalism, transmitted through magazines, as well as descriptions of European beggars' lives published there, were designed to change the traditional stereotype based on the Russian religious vision of beggars as saints. As Jahn shows, this goal was only partly achieved. In the milieu of intellectual and political elite the europeanization of the mind did happen, but the majority of the population continued to live in the framework of the old cultural tradition, seeing beggars as people "pleasing to God" (from which the Russian word ubogii, "pauper" - $u$ Boga - originated) and giving alms as a salvation of the soul.

Conservation of the traditional attitude towards poverty, according to Jahn, can explain why measures of the authorities and of the police against begging were not understood and supported by the population. The steadiness of the tradition was one of the main reasons why the authorities failed to solve the problem of beggary by law. This project was utopian from the very beginning of its realization (p. 150-151).

11 The USSR inherited the problem of beggary from the Russian Empire. Soviet academic study of the struggle against poverty still remains rather fragmentary. Unfortunately, Jahn's book does not add much to the research on this topic. The author says that he consciously refused to study Soviet archival materials dealing with beggary because the very existence of beggary in the USSR was not officially recognized before Perestroika (p. 19).

This statement is only partly true. Basically, from the end of the 1920s till the mid-1950s in the Soviet mass sources the problem of beggary was not discussed. In that time period the authorities tried to eliminate poverty with the introduction of the passport system and with secret instructions (a secret decree against beggars was released in 1951). In 1954 however, the theme of beggary became public again and for the first time after a 30-year break this problem became the object of the government's interest. In the 1960s, beggary ceased to be a mass phenomenon in the USSR and either became a profession or remained on a small scale. Beggary re-emerged in Russia after the fall of the Soviet Union. This very fact makes the Soviet experience of dealing with beggary worth studying. 
13 In the meantime, there is nothing we can do but regret that Jahn's book about beggary in Russia is not translated into Russian.

\section{NOTES}

1. The study of practices of inclusion/exclusion of the "alien and poor» in several European countries was done within the framework of an international project initiated by Trier university (Germany). The results of the Trier project are presented in several publications: B. Althammer, ed., Bettler in der europäischen Stadt der Moderne: Zwischen Barmherzigkeit, Repression und Sozialreform, Frankfurt-am-Main, 2007; A. Gestrich, L. Raphael, eds., Inklusion/Exklusion: Studien zu Fremdheit und Armut von der Antike bis zur Gegenwart, Frankfurt-am-Main, 2004; L. Raphael, H. Uerlings, eds., Zwischen Ausschluss und Solidarität: Modi der Inklusion/Exklusion von Fremden und Armen in Europa seit der Spätantike, Frankfurt-am-Main, 2004. 